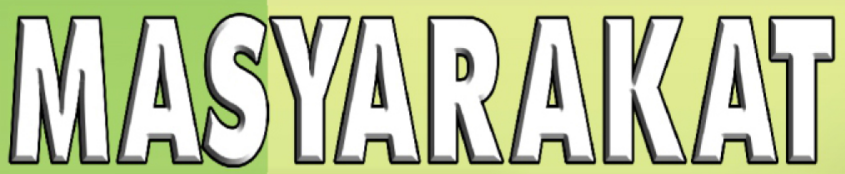

Terakreditasi No. 21/E/KPT/2018
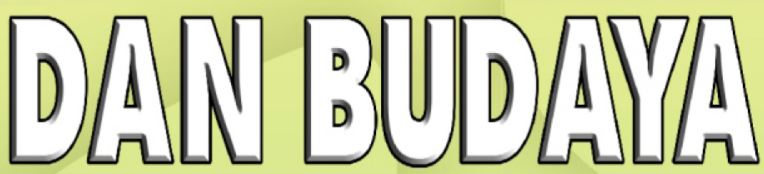

Volume 22 No. 12020

Karakter Keberagamaan di Jawa Pasca Geertz

Gutiono Bayu AJ]

Dayak Kaharingan di Tengah Perubahan Sosial Ekologi dan Praktik Perpindahan Agama dl Perdesaan Kalimantan Tengah

Nindyo Budi Kumoro

MarjinalisasI Hukum Adat pada Masyarakat Adat

The Suartina

Nasionalisme Masyarakat Natuna

Budlana Sotlawan

Frontierisation dan Defrontierisation Sebagal Kerangka untuk Studl Marjinalitas: Kasus Dataran Lindu di Sulawesi Tengah

Greg Acclalo/f dan Muhammad Nasrum

Marjinalisasi Perempuan Kuli Panggul di Pasar Pabean Surabaya

Mitranth Dwi Yuntart

Mencipta Ruang, Menggapal Langit: Pendidikan Publik Kritis dan Ruang Alternatif Minoritas di Yogyakarta dan Bandung Melke Lusye Karrolus dan Firchan Arta Wilaya

Adaptasi Sosial Gay Muslim Indonesia Terhadap Agama dan Keluarga Wisnu Adthariono 


\section{Daftar Isi \\ Jurnal Masyarakat dan Budaya \\ Volume 22 No. 1 Tahun 2020}

Pengantar Redaksi

Halaman

Topik:

iii

Ø5 Karakter Keberagamaan di Jawa Pasca Geertz

Gutomo Bayu Aji

\5 Dayak Kaharingan di Tengah Perubahan Sosial Ekologi dan Praktik Perpindahan Agama di Perdesaan Kalimantan Tengah

Nindyo Budi Kumoro

\5 Marjinalisasi Hukum Adat pada Masyarakat Adat

Tine Suartina

\5 Nasionalisme Masyarakat Natuna

Budiana Setiawan

\5 Frontierisation dan Defrontierisation Sebagai Kerangka untuk Studi Marjinalitas: Kasus Dataran Lindu di Sulawesi Tengah

Greg Acciaioli dan Muhammad Nasrun

§5 Marjinalisasi Perempuan Kuli Panggul di Pasar Pabean Surabaya

Miranti Dwi Yuniarti

\5 Mencipta Ruang, Menggapai Langit: Pendidikan Publik Kritis dan Ruang Alternatif Minoritas di Yogyakarta dan Bandung

Meike Lusye Karolus dan Firdhan Aria Wijaya

\5 Adaptasi Sosial Gay Muslim Indonesia Terhadap Agama dan Keluarga

Wisnu Adihartono

\section{Tinjauan Buku:}

\5 Membicarakan Masyarakat Pinggiran di Indonesia

Riwanto Tirtosudarmo 


\title{
MENCIPTA RUANG, MENGGAPAI LANGIT: PENDIDIKAN PUBLIK KRITIS DAN RUANG ALTERNATIF MINORITAS DI YOGYAKARTA DAN BANDUNG
}

\section{CREATING THE SPACE, REACHING THE SKY: CRITICAL PUBLIC PEDAGOGY AND ALTERNATIVE SPACE FOR MINORITIES IN YOGYAKARTA AND BANDUNG}

\author{
Meike Lusye Karolus \\ Universitas Pembangunan Nasional "Veteran" Yogyakarta \\ meike.karolus@upnyk.ac.id \\ Firdhan Aria Wijaya \\ Panggung Minoritas \\ firdhanariawijaya@gmail.com
}

\begin{abstract}
Since 2016, there have been several cases in intolerance towards minority groups in Yogyakarta and Bandung. Those actions were triggered by conservative-extremist religious groups which are seemingly becoming a powerful source for disintegration as well as threats to the freedom of expression and diversity. With the lack of protection from regional government apparatus, initiative grassroots movements tend to find alternative ways that open possibilities to create a space for minority groups. In Yogyakarta, there is Pemetik Buah Khuldi, a community which provides alternative critical public education related to diversity issues and democracy. Meanwhile in Bandung, there is Panggung Minoritas, an initiative that creates a safe space for gender and sexual minorities to meet, share, learn and discuss gender and sexuality topics. Both groups have similar purposes which cultivate awareness and support minority rights through education, support groups, and creative activities. By examining both independent communities' activities through an ethnographic approach, we analyze how these groups are becoming prevalent in the area of Java where there are high numbers of intolerances and the reason why they prefer grassroots movement to government-approved groups to support minority groups. Furthermore, this article seeks to contribute a relevant perspective on the recent situation of marginal groups and part of our critical reflection on responding to common project failure to recognise diversity.
\end{abstract}

Keywords: grassroots, minority group, disintegration, intolerance

\begin{abstract}
Abstrak
Sejak tahun 2016, intoleransi terhadap kelompok minoritas marak muncul di Yogyakarta dan Bandung. Tindakan-tindakan itu dipicu oleh sederet kelompok agama tertentu yang konservatif nan ekstremis. Kelompokkelompok tersebut berpotensi menjadi sumber kuat untuk disintegrasi bangsa dan ancaman terhadap kebebasan berekspresi dan keberagaman. Dengan kurangnya perlindungan dari aparat pemerintah daerah, inisiatif gerakan akar rumput cenderung menempuh cara-cara alternatif untuk menciptakan ruang bagi kelompok-kelompok minoritas. Di Yogyakarta, terdapat Pemetik Buah Khuldi, sebuah komunitas yang menyediakan alternatif pendidikan publik kritis terkait dengan isu keberagaman dan demokrasi. Sementara itu, di Bandung, terdapat Panggung Minoritas, sebuah komunitas yang berinisiatif menciptakan ruang yang aman bagi minoritas gender dan seksual untuk bertemu, berbagi, belajar, dan mendiskusikan topik gender dan seksualitas. Kedua kelompok tersebut memiliki tujuan yang sama, yaitu menumbuhkan kesadaran dan mendukung minoritas melalui dialog, kepedulian kolektif, dan kegiatan kreatif. Dengan menelusuri aktivitas kedua komunitas tersebut melalui pendekatan etnografi, kami menganalisis bagaimana keduanya hadir di tengah meningkatnya jumlah intoleransi di pulau Jawa dan motivasi di balik mengapa mereka lebih memilih gerakan akar rumput daripada kelompok yang ditunjuk secara resmi untuk membantu minoritas. Selain itu, artikel ini berupaya memberikan kontribusi untuk mengisi perspektif yang relevan mengenai situasi terkini kelompok marginal dan bagian dari refleksi kritis dalam merespons kegagalan mengenali keberagaman.
\end{abstract}

Kata kunci: akar rumput, kelompok minoritas, disintegrasi, intoleransi

Jurnal Masyarakat \& Budaya, Volume 22 No. 1 Tahun 2020 


\section{Pendahuluan}

"Apa yang bisa kita lakukan?”, adalah pertanyaan yang menggelisahkan sembilan anak muda di Yogyakarta dan lima profesional di Bandung. Kegelisahan mereka dipicu intensitas tindakan intoleransi terhadap kelompok minoritas yang meningkat sejak 2016. Represi tersebut didasari oleh perbedaan identitas dan sentimen terhadap etnis, ras, suku, agama, kelas, golongan, ideologi, maupun seksualitas (Ridwan dan Wu, 2018; Mietzner dan Muhtadi, 2019). Berbagai tindakan intoleransi itu kebanyakan digerakkan oleh kelompok konservatif-ekstrimis dengan menggunakan simbol agama tertentu sehingga tampak memiliki otoritas ilahiah yang tidak terbantahkan. Kelompok-kelompok itu tidak saja mendatangi tempat berkumpul kelompok minoritas, tetapi juga berusaha membatalkan diskusi publik dengan topik yang dianggap sensitif seperti seksualitas atau Tragedi 65 yang berujung menghalangi akses publik untuk mendapatkan informasi dan pengetahuan. Di tengah peliknya situasi itu, sikap pemerintah daerah setempat dirasa kurang tegas menindak kelompok-kelompok yang menindas dan kurang gigih melindungi kelompok minoritas.

Tidak bisa dipungkiri bahwa tindakan intoleransi terhadap minoritas juga sudah pernah terjadi sebelumnya, tetapi pada tahun 2016 , isuisu perbedaan identitas menjadi diskursus publik dan mengundang pemerintah untuk mengeluarkan pernyataan yang sayangnya sebagian dinilai diskriminatif $(B B C, 2016$; Widhana, 2017; ASEAN SOGIE Caucus, 2018). Kurangnya perlindungan dari pemerintah (level top-down) membuat masyarakat, khususnya para anak muda, tergerak melakukan sesuatu dengan menggunakan pendekatan akar rumput (level bottom-up) untuk merangkul dan membekali masyarakat agar memiliki kesadaran dan basis pengetahuan agar terlibat aktif dalam proses demokrasi.

Di Yogyakarta, tindakan intoleransi kerap terjadi meskipun secara kultural sangat terbuka dengan keberagaman (de Jong \& Twikromo, 2017). Sembilan anak muda tersebut berasal dari golongan kelas menengah terdidik yang bekerja sebagai akademisi, aktivis, karyawan swasta, dan pelajar. Persinggungan rasa empati dan niat untuk berpihak pada kelompok minoritas (gender, seksual, etnis/ras/ suku, kelas, dan antariman) mendorong mereka untuk menciptakan ruang alternatif pendidikan publik kritis. Ruang alternatif itu terbentuk sejak Januari 2018 dan diberi nama Pemetik Buah Khuldi (PBK).

Komunitas ini mengambil filosofi buah khuldi (dalam tradisi Islam) atau buah pengetahuan tentang yang baik danjahat (tradisi Kristen) yang dimaknai secara kritis sebagai simbol resistensi terhadap kenyamanan dunia yang tampak baik-baik saja. Dalam tafsiran yang tradisional, Adam dan Hawa yang memetik dan memakan buah khuldi/pengetahuan dimaknai sebagai pemberontakan kepada Tuhan. Komunitas tersebut memaknai kembali peristiwa itu sebagai keberanian menggunakan pengetahuan untuk keluar dari rasa aman "surgawi" dan jalan heroik untuk menghadapi berbagai penindasan. Spirit itu sejalan dengan tradisi kritis ilmu sosial.

Tabel 1

Catatan Tindakan Intoleransi di Yogyakarta dan Bandung Januari 2016-Juli 2019

\begin{tabular}{|c|l|l|l|}
\hline No. & Tahun & \multicolumn{1}{|c|}{ Yogyakarta } & \multicolumn{1}{|c|}{ Bandung } \\
\hline 1. & 2016 & $\begin{array}{l}\text { Pemaksaan penutupan Pesantren Waria } \\
\text { Al-Fattah oleh Front Jihad Islam (FJI). }\end{array}$ & $\begin{array}{l}\text { Pernyataan publik oleh walikota Bandung } \\
\text { yang menyatakan bahwa LGBT tidak } \\
\text { boleh diekspos dan dikampanyekan. }\end{array}$ \\
\hline 2. & 2016 & $\begin{array}{l}\text { Pelarangan diskusi dan nonton film } \\
\text { "Pulau Buru Tanah Air Beta" di UGM. }\end{array}$ & $\begin{array}{l}\text { Pembubaran perayaan Malam Natal oleh } \\
\text { Pembela Ahlu Sunnah (PAS). }\end{array}$ \\
\hline 3. & 2016 & $\begin{array}{l}\text { Pelarangan billboardpromosi kampus } \\
\text { dengan mahasiswi mengenakanhijab di } \\
\text { Universitas Kristen Duta Wacana dan } \\
\text { Universitas Sanata Dharma. }\end{array}$ & Pelarangan diskusi tentang LGBT di ITB. \\
\hline 4. & 2018 & $\begin{array}{l}\text { Serangan di Gereja Katolik St.Lidwina, } \\
\text { Bedog, oleh seorang pria yang membawa } \\
\text { pedang. Insiden ini menyebabkan Rm. } \\
\text { Karl Edmund Prier, SJ terluka. }\end{array}$ & $\begin{array}{l}\text { Polisi menangkap dua orang pria di } \\
\text { rumahnya karena membuat sebuah grup } \\
\text { di media sosial Facebook untuk } \\
\text { kelompok gay. }\end{array}$ \\
\hline 5. & 2018 & $\begin{array}{l}\text { Insiden pemotogan salib di makam } \\
\text { Purbayan. }\end{array}$ & $\begin{array}{l}\text { Persekusi terhadap kelompok Syiah yang } \\
\text { merayakan hari Asyura. }\end{array}$ \\
\hline
\end{tabular}




\begin{tabular}{|c|l|l|l|}
\hline No. & \multicolumn{1}{|c|}{ Tahun } & \multicolumn{1}{c|}{ Yogyakarta } & \multicolumn{1}{c|}{ Bandung } \\
\hline 6. & $\begin{array}{l}2016,2018, \\
2019\end{array}$ & $\begin{array}{l}\text { Represi terhadap Mahasiswa Papua di } \\
\text { Asrama Mahasiswa Papua. }\end{array}$ & $\begin{array}{l}\text { Pelarangan diskusi buku di Masjid } \\
\text { Ahmadiyah oleh Front Pembela Islam dan } \\
\text { Jawara Sunda. }\end{array}$ \\
\hline
\end{tabular}

Sumber: Data penulis yang dilansir dari berbagai media dan data sekunder

Gejala yang sama juga muncul di Bandung. Beda kota, maka beda konteks. Bila Yogyakarta dianggap sebagai Indonesia mini yang plural, Bandung memiliki karakteristik yang unik. Meski sangat kosmopolit, Bandung, dan lebih luas lagi Jawa Barat, tidak bisa dilepaskan dari sejarah pembentukan Negara Islam Indonesia (NII) pada dekade 1950-an (Formichi, 2012). Hal itu kemudian menjadi akar bagi tumbuh suburnya kelompok-kelompok dengan paham pemurnian ajaran di wilayah itu. Di tengah himpitan paham Islam ideologis yang kuat, diskursus gender, dan seksualitas hampir tidak memiliki tempat.

Pada Juli 2018, Panggung Minoritas (PM) lahir di Bandung sebagai bentuk atensi terhadap studi mengenai isu-isu gender dan seksualitas yang absen dalam sistem pendidikan formal dan dorongan untuk membicarakan topik tersebut dalam ruang yang aman, intim, dan personal. Inisiasi tersebut juga memberikan kesempatan bertemunya para minoritas gender dan seksual serta publik yang ingin belajar dan berbagi pengalaman mengenai topik-topik spesifik terkait gender dan seksualitas. Hampir sama dengan PBK, PM didirikan oleh lima orang yang datang dari generasi yang berbedabeda dan mereka berasal dari kelas menengah dengan ragam profesi seperti tenaga medis, peneliti, aktivis, dan karyawan swasta. Filosofi "panggung" membukakan peluang agar para "minoritas" dapat tampil, berbicara, dan menunjukkan ekspresi diri tanpa rasa takut, malu, atau pun merasa dihakimi. Di "panggung minoritas" inilah, para liyan dapat bebas menjadi diri mereka yang tidak pernah didapatkan dalam tatanan sosial yang heteronormatif.

Baik PBK maupun PM, keduanya memiliki tujuan yang sama untuk menanamkan kesadaran dan mendukung tercapainya hak-hak kelompok minoritas melalui pendidikan, kepedulian kolektif, dan kegiatan kreatif. Kedua komunitas juga menjalin kerja sama dan kolaborasi dengan berbagai institusi, komunitas, maupun individu untuk membentuk jejaring kolektif yang saling bersinergi.
Tulisan ini mengkaji dua hal: (1) Bagaimana PBK dan PM hadir di Yogyakarta dan Bandung yang notabene menjadi kota dengan jumlah intoleransi yang cukup tinggi?; (2) Apa motivasi yang menjiwai kedua komunitas untukmemilih gerakan akar rumput daripada kelompok yang memiliki kewenangan terkait isu minoritas? Sebagaiupaya merawat pengetahuan, artikel ini berkontribusi untuk mengisi perspektif yang relevan mengenai situasi terkini kelompok marginal dan bagian dari refleksi kritis dalam merespons kegagalan mengenali keberagaman.

\section{Posisi Penulis dalam Merangkai Riset}

Adapun hal-hal yang perlu diperhatikan adalah bagaimana kami merancang penelitian dan posisi kami dalam riset. Penelitian ini merupakan riset multidisiplin yang bersifat interseksional antara kajian sosiologi, komunikasi, antropologi, dan politik. Paradigma ilmu yang kami gunakan adalah paradigma kritis dalam ilmu sosial-humaniora. Di titik ini, kami membutuhkan metodologi yang queer yang dapat menembus batas-batas metode yang ketat dan dapat dikombinasikan dengan pendekatan lain seperti mengawinkan etnografi dengan pendekatan tekstual (Halberstam, 1998:10). Sebagai salah satu dari inisiator kedua komunitas, kami juga menyadari bahwa persoalan etika tidak bisa dihindari.

Pada situasi dan level ini, kami perlu memosisikan diri sebagai peneliti dan sekaligus menyadari peran kami sebagai bagian dari komunitas yang diteliti. Dengan demikian, kami membutuhkan metodologi queer untuk berhadapan dengan subjektivitas yang cair, tidak stabil, dan berada dalam proses untuk "menjadi" (Browne dan Nash, 2010). Sebagai peneliti, perhatian dan kemelekatan pada yang diteliti menjadi roh yang mendiami penelitian. Batas-batas antara komunitas dan peneliti yang merupakan bagian dari komunitas menjadi cair dan menunjukkan suatu upaya penyatuan kerja akademikaktivisme. 
Data utama diperoleh dengan metode indepth interview terhadap para pendiri komunitas dan orang-orang yang terlibat dengan komunitas, baik sebagai anggota komunitas, partisipan, maupun pembicara. Pemilihan informan berdasarkan kualifikasi bahwa mereka memang pernah/terlibatdengan komunitas dan secara konsisten mengikuti kegiatan kedua komunitas. Metode in-depth interview kemudian diperkuat dengan metode observasi yang diaplikasikan dalam kegiatan-kegiatan komunitas. Data sekunder diperoleh dengan menggunakan analisis teks untuk memeriksa dokumen kedua komunitas, seperti notula, konten sosial media, dan materi publikasi. Tujuannya adalah untuk melihat kesesuaian antara cita-cita komunitas dengan produksi teks yang dihasilkan. Penelitian ini dilaksanakan antara Juni-September 2019. Dengan mempertimbangkan keamanan dan kenyamanan informan, maka semua nama informan yang diwawancarai dalam penelitian ini disamarkan.

\section{Membicarakan Subaltern dalam Demokrasi yang Deliberatif}

Diskursus tentang minoritas mengantar pada kerangka konsep tentang subaltern. Spivak (1988) mengonseptualisasikan kembali subaltern dengan menekankan cara pandang untuk melihat subjektivitas yang direpresentasikan dan kerangka pandangan yang dibentuk untuk melihat subjektivitas tersebut. Relasi antara kelompok dominan dan subaltern ditentukan oleh stratifikasi produksi sosial dengan kontrol dan kuasa sebagai tolak ukurnya. Relasi itu juga menciptakan ambiguitas dan kontradiksi dalam pembentukan aliansi karena kelompok yang mendominasi di suatu area dapat menjadi kelompok yang didominasi di area yang lain. Boleh dikatakan bahwa subaltern adalah jenis minoritas yang paling minoritas karena mereka tidak saja menempati strata yang lebih rendah, tetapi juga tidak mendapat tempat untuk "menyuarakan" diri mereka sendiri.

Argumen Spivak tentang suara subaltern yang absen dapat dipikirkan kembali. Ketiadaan suara bukan berarti absen sama sekali, melainkan oleh Rajeshwari Sunderajan (Das, 2011) disebut sebagai suatu kegagalan dalam resistensi. Nyanyian subaltern memang tidak menyatakan perlawanan, tetapi mengiramakan kesadaran atas ketidakberdayaan yang menyentuh hingga mampu terdengar lintas zaman (Das, 2011). Di sisi lain, diperlukan strategi yang riil untuk menyuarakan pengalaman liyan. Menurut Hiddleston (2007) subaltern perlu hadir sebagai agensi yang menyediakan pemahaman alternatif. Dia menggunakan kisah Echo dan Narcissus dalam mitologi Yunani untuk menggambarkan bahwa subaltern juga berdaya. Echo menyimbolkan subaltern yang membangkitkan kemungkinan representasi diri melalui suara yang ditirukan berulang-ulang di luar kehendak Narcissus yang melambangkan kelompok dominan. Dengan demikian, "suara" liyan yang bergema dapat menjadi representasi di ruang publik meskipun kecil kemungkinan mendapat respons.

Kebutuhan ruang-ruang alternatif menjadi salah satu strategi dalam proses demokrasi di Indonesia. Di tengah berbagai tindakan intoleransi terhadap kelompok minoritas, proses demokrasi menjadi mandek karena banyak suara yang dibungkam. Freedman dan Tirbuzi (2012) menemukan wajah demokrasi Indonesia pascaReformasi tidak bisa lepas sepenuhnya dari persoalan korupsi, kekerasan militer, absennya perlindungan hak-hak minoritas, dan radikalisme Islam. Demokrasi lahir dari rakyat manakala di antara sesama warga negara yang berpikir menyatakan kepentingan mereka kepada negara. Namun, dalam upaya perlindungan terhadap kelompok sipil, terutama minoritas, terdapat celah yang dalam bahwa pihak yang seharusnya melindungi pun justru melakukan kekerasan terhadap hak-hak mereka (Freedman dan Tirbuzi, 2012).

Relasi mayoritas-minoritas yang timpang tampak dari beberapa kasus berikut ini. Pertama, tantangan terhadap proses demokrasi dapat dipicu oleh lembaga keagamaan yang memiliki otoritas untuk mengendalikan opini publik. Sebagai contoh, fatwa-fatwa Majelis Ulama Indonesia (MUI) seringkali menjadi percikan api yang menegaskan perbedaan antara umat Muslim dengan non-Muslim (Nasir, 2014).

Kedua, model "disiplin" ala klientelisme dan vigilantisme berpengaruh secara informal dalam memaksakan kuasa dan kontrol kepada jaringan dan bahkan institusi formal sehingga minoritas mengalami perlakuan diskriminatif, tidak mendapatkan perlindungan, dan kesulitan mengakses hak-haknya (Soedirgo, 2018; Suryana, 2019).

Ketiga, pemaksaan nilai dan aturan mayoritas kepada minoritas yang ternyata dapat mengubah perspektif minoritas terhadap identitas mereka. Misalnya, Parker (2017) 
menemukan situasi yang kolonial terjadi di Bali ketika aturan memakai hijab di sekolah dilarang oleh institusi formal yang dikuasai mayoritas Hindu. Akibatnya, terdapat pergeseran pemaknaan hijab di kalangan para siswi minoritas Islam, dari sesuatu yang religius menjadi sekuler bahkan kerap diasosiasikan dengan ketertinggalan atau kelompok kelas bawah.

Dalam suasana berdemokrasi yang polutif ini, masyarakat sipil perlu bergerak dan menciptakan ruang-ruang alternatif yang dapat menciptakan demokrasi yang deliberatif serta memberi panggung bagi subaltern. Festenstein (2004) mengemukakan bahwa demokrasi deliberatif sebagai suatu proses ideal pembuatan keputusan yang demokratis. Proses tersebut menekankan diskusi publik terhadap argumentasi dan tawaran politis hingga kemudian dinilai untuk diterima atau ditolak oleh publik.

Teori Habermas mengenai tindakan komunikasi kemudian dipakai untuk menjawab objek problematisasi yang disebut sebagai diskursus. Menurut Habermas (Hardiman, 2009: 59) masyarakat modern cenderung jatuh pada interaksi-interaksi strategis yang terlepas dari konteksnya sehingga hanya mengutamakan kepentingan diri daripada kepentingan bersama. Pada titik itulah, masyarakat perlu memahami kekuasaan komunikatif sebagai kedaulatan sebuah kesatuan sosial yang akan terbentuk apabila mereka berbicara dan bertindak satu sama lain (Hardiman, 2009:95). Kontrol atas pemerintah dilaksanakan dengan mengendalikan opini publik sebagai cerminan atas kepentingan semua orang. Model demokrasi deliberatif memastikan bahwa rakyat dapat memiliki andil dalam keputusan-keputusan politis, termasuk kemudian sadar bahwa opini-opini mayoritas terbentuk agar semua orang patuh pada aturan tersebut. Dengan melihat keadaan tersebut, masyarakat perlu dicerdaskan agar aktif berpartisipasi politik sehingga proses demokrasi dapat berjalan dengan sehat.

\section{Ruang Transit: Dekonstruksi dan Gerakan Akar Rumput}

Pembentukan wacana pembangunan memberikan pengaruh yang luar biasa membekasnya bagi negara-negara yang dianggap berkembang dan bahkan tertinggal. Wacana pembangunan menjadikan negara-negara tersebut fokus pada perekonomian yang menjamin kehidupan yang lebih baik. Berbagai strategi dan program digalang untuk menyusul ketertinggalan dengan negara-negara yang dianggap maju bahkan ada beberapa yang menjiplak apa yang telah negaranegara maju lakukan demi keberhasilan yang berbuah kesejahteraan untuk rakyatnya. Namun, benarkah jaminan itu terpenuhi?

Escobar (1990) menjelaskan resep yang diajukan oleh negara-negara maju untuk "mendukung dan mendorong" negara-negara lain dalam menyokong perekonomian mereka telah memberikan perubahan yang signifikan pada manusia dan lingkungan yang cenderung destruktif. Itikad negara-negara maju tersebut membentuk relasi kuasa yang timpang dan dibaliknya cenderung memiliki agenda terselubung yang bermuatan politis. Fokus negara-negara berkembang dan bahkan tertinggal untuk menyejahterakan rakyatnya menjadi kabur karena adanya pengaruh neoliberalisme yang kuat. Pengaruh tersebut menyebabkan distribusi perekonomian yang tidak merata, mengikisnya pengetahuan lokal, dan tertanamnya pemikiran yang heteronormatif. Ketiga pengaruh tersebut mendorong semakin terpinggirnya minoritas dari tatanan sosial masyarakat. Tidak hanya itu, tendensi pembangunan yang mengarah pada infrastruktur saja mengakibatkan kerusakan lingkungan yang kompleks seperti hilangnya keragaman hayati, kelangkaan sumber daya tertentu, dan kontribusi yang signifikan terhadap perubahan iklim.

Kiprah pembangunan Indonesia telah memperlebar jarak antara mayoritas dan minoritas. Hal tersebut telah mempersempit ruang-ruang minoritas untuk menemukan eksistensinya dan memperuncing pemisahan minoritas. Namun, minoritas yang berasal dari lapisan akar rumput tidak akan bergelagat diam dan berusaha bergerak dengan cara-cara yang tidak biasa untuk bernegosiasi dengan keadaan tersebut. Resistensi itu, menurut Edelman (2001), ditunjukkan dengan aksi bersama yang membentuk alternatif-alternatif yang terus berkembang untuk bernegosiasi dengan lingkungan yang didominasi oleh industri yang kapitalistik dan sistem patriarki. Kembali mengutip Escobar (1990), aksi bersama tersebut biasanya disadari oleh kelas menengah yang merasakan opresi ataupun menjadi bagian dari minoritas tersebut. Aksi bersama itu membentuk sebuah autonomy dan representasi yang berani menyuarakan tentang diri atau komunitasnya sebagai pembeda dari logika mainstream dalam tatanan masyarakat. 
Tidak hanya itu, aksi bersama tersebut merebut ruang-ruang yang tidak lazim yang sebelumnya dikuasai oleh ruang-ruang yang terlalu patriarki nan heteronormatif. Gerakan akar rumput mengonstruksi ulang ruang tersebut menjadi sesuatu yang lebih cair yang secara spesifik berusaha untuk menghilangkan keajegan-keajegan yang menghambat proses interaksi dan menambahkan sensitivitas terhadap makna inklusivitas. PBK dan PM, misalnya, secara tidak sadar melakukan queering pada ruang-ruang cis-heteronormatif sehingga ruang itu dapat diklaim oleh minoritas. Ruang itu juga dapat digunakan sebagai ruang transit yang memungkinkan terjadinya pertemuan antara minoritas-minoritas ataupun pertemuan dengan masyarakat publik yang ingin belajar dan berinteraksi bersama (Gieseking, 2013).

\section{Narasi Pengetahuan yang Berasal dari Bawah}

Dalam masyarakat modern, pengetahuan lazimnya diwadahi oleh lembaga formal yang memiliki standar dan aturan. Namun, dengan mempertimbangkan situasi akhir-akhir ini, tidak semua ruang formal yang dominan dapat menampung isu-isu minoritas. PBK dan PM muncul sebagai ruang alternatif yang terbuka menerima hal itu. Melalui diskusi bulanan, diskusi khusus, dan workshop, PBK menjadi ruang alternatif yang dipilih publik Yogyakarta dan sekitarnya untuk mengakses pengetahuan mengenai isu-isu minoritas.

Menurut Halim (32 tahun, karyawan swasta), salah satu partisipan PBK, selama mengikuti diskusi PBK dia mendapatkan banyak pengetahuan baru yang ternyataada atau terjadi di daerah lain yang selama ini tidak didapatnya melalui media mainstream. "Tentu perkembangan isunya bisa diikuti via sosial media, tetapi jika hal itu dibahas dalam forum bisa dikatakan lebih valid," ujarnya. Bagi Halim, ruang alternatif yang disediakan PBK ternyata menjembatani antara pengalaman pribadi dengan ruang baru ketika tinggal di Yogyakarta. Seperti filosofi Jawa tumbu ketemu tutup, Halim yang tadinya menyimpan keresahan atas situasi di sekitarnya akhirnya menemukan wadah untuk berbagi pikirannya dan belajar untuk memahami realitas tersebut.

Hampir sejalan dengan Halim, Yuna (24 tahun, mahasiswi pascasarjana) juga menceritakan pengalamannya. Yuna dulunya merupakan salah satu peserta diskusi PBK yang kemudian menjadi anggota komunitas PBK. Dia tertarik mengikuti diskusi PBK karena namanya yang terkesan unik dan memanggil. Ketika pertama kali pindah ke Yogyakarta, Yuna membandingkan ada gap wacana tentang minoritas di kotanya dulu (Makassar) dengan di Yogyakarta. Di sinilah, dia merasa PBK bisa mengisi gap wacana tersebut. "Darahnya PBK itu langsung berpihak pada kelompok minoritas. Di sana aku menemukan teman-teman yang se-frekuensi," tuturnya. Berdasarkan penjelasan Halim dan Yuna, PBK menjawab kebutuhan akan ruang bagi mereka yang mencari pengetahuan tentang minoritas. Dengan mempertimbangkan demografi partisipan PBK yang merupakan mahasiswa, pekerja, dan sebagian besar datang dari luar kota Yogyakarta, maka dapat dianggap bahwa PBK menjadi rumah bagi bertemunya keberagaman publik yang meleburkan batas antara pendatang dan penduduk asli kota Yogyakarta.

Seperti halnya PBK, PM memberikan pemahaman melalui diskusi bulanan tentang ruang belajar yang tidak harus selalu bersifat formal tetapi bisa dapat dilakukan dengan lebih intim, personal, aman, dan menyenangkan tetapi serius. PM menggagas model belajar dengan menekankan pendekatan individu sehingga membuat peserta yang hadir nyaman untuk bertukar pikiran. Hal tersebut diungkapkan oleh Aira (25 tahun, dokter), salah satu partisipan PM, yang selalu menyambut baik diskusi-diskusi bulanan, "Senang bisa bersama-sama orangorang yang ajaib yang membuat suasana hati lebih nyaman". Di samping itu, PM membuka kesempatan bagi setiap individu untuk berbagi cerita personal mereka di setiap diskusinya.Salah satu pendiri PM, Marbun (40 tahun, dokter) menekankan "everybody has their own struggles and stories" yang membawa semangat PM untuk mendengarkan apa yang dirasakan dan yang dialami partisipannya sehari-hari.

Walaupun PM mengundang narasumber yang ahli di bidang terkait gender dan seksualitas setiap bulannya, bukan berarti PM menggantungkan pengetahuan sepenuhnya dari narasumber tersebut saja (top-down approach). Sejalan dengan Michel Foucault, knowledge from below menjadi sesuatu yang penting untuk membentuk suatu pengetahuan yang relevan dan dekat serta mencerminkan keseharian masyarakat (Halberstam, 2011). Sebagai upaya untuk menghargai cerita-cerita yang personal tersebut, PM selalu memastikan selama berlangsungnya proses dan setelah aktivitas 
selesai, para peserta terlindungi dan rahasia mereka terjamin. Hal itu membentuk adanya rasa percaya di antara sesama partisipan sehingga menciptakan ikatan persaudaraan yang kuat.

Pengetahuan tersebut juga tidak hanya bagi mereka yang membutuhkan, tetapi juga dapat berasal dari keinginan orang-orang yang ingin berbagi pengetahuan. Menurut Rena (28 tahun, peneliti), salah satu co-founder PBK, selain menghadirkan narasumber yang memiliki perspektif menarik untuk merespons isu-isu minoritas, PBK juga memberi ruang bagi para narasumber. "Tidak cuma bagi peserta yang ingin mendapatkan pengetahuan, tetapi juga narasumber yang ingin membagi pengetahuan," ujarnya. Penuturan Rena diamini Karin (33 tahun, dosen) yang pernah menjadi pembicara dalam diskusi PBK. "PBK menjadi media pembelajaran bagi pembicara karena peserta diskusi yang datang berasal dari berbagai latar belakang sehingga penyampaian materi tentu perlu mempertimbangkan kemampuan peserta, seperti apakah mereka sudah memahami konsep-konsep dasar atau belum," ujar Karin.

Hasrat saling berbagi pengetahuan pun dialami oleh PM. Partisipan yang hadir dalam kegiatan PM sangat beragam latar belakangnya, terutama mengenai sampai sejauh mana partisipan terpapar studi-studi mengenai gender dan seksualitas. Sebagian sudah mengenal dan memahami dengan baik isu gender dan seksualitas, tetapi sebagian masih meraba-raba atau bahkan tidak pernah terpapar pengetahuan mengenai isu tersebut. Ada juga yang lemah di topik tertentu terkait gender dan seksualitas, namun kuat di topik lain dan begitu pula sebaliknya. Hal tersebut tidak menjadi masalah mengingat proses berbagi pengetahuan dilakukan dengan sesi diskusi kelompok yang lebih kecil skalanya. Tujuan aktivitas itu untuk memperdalam isu yang didiskusikan dan memancing partisipan untuk bercerita tentang pengalaman yang dialami. Proses tersebut memungkinkan pengetahuan dapat terbagi rata tanpa satu yang mendominasi dan tidak mengecilkan satu yang belum mengerti.

Mengutip dua pendiri PM, Marbun dan Aris (34 tahun, aktivis), diskusi kelompok selalu dibutuhkan untuk mencapai proses unlearn, learn, dan relearn. Satu partisipan yang sudah mengetahui isu tertentu mengenai gender dan seksualitas tentu dapat berbagi ilmunya dalam kelompok. Namun, dia pun akan belajar kembali dari berbagai pengalaman masing-masing partisipan dengan konteks tertentu. Proses tersebut menyebabkan adanya interaksi yang sehat di antara sesama partisipan. Dalam skala individu, aktivitas itu diharapkan dapat menciptakan kerendahan hati untuk mendengarkan satu sama lain dan merefleksikan diri untuk berempati serta memandang bahwa segala sesuatu bukan hanya terpusat untuk dirinya sendiri atau de-centering process.

Dalam berkomunitas, PBK mengaplikasikan metode pendidikan yang cair melalui diskusi dan dialog dengan tujuan memberikan afirmasi pengetahuan peserta yang sudah ada sebelumnya dan membantu mereka mengurai prasangka terhadap stereotipe yang berlaku secara umum di masyarakat. Tradisi kritis dalam ilmu sosial dan humaniora digunakan sebagai pijakan, meskipun tidak menutup kemungkinan terjadi persinggungan dengan paradigma dan ilmu lain. Tentu saja, aktivitas tersebut tidak berhenti pada ruang diskusi. Masing-masing peserta diharapkan membawa misi ketika kembali beraktivitas sehari-hari. Pertama, para anggota PBK diharapkan mampu mengenali masalah di tengah masyarakat. Kedua, mereka memiliki perspektif untuk membaca akar permasalahan. Ketiga, mereka dapat menjadikan diri sebagai agensi. Pada titik-titik itulah, mengikuti spirit Spivak, PBK muncul untuk menghadirkan representasi diri dan menyuarakan pengalaman liyan dalam konteks yang adil dan setara.

Serupa dengan PBK, PM mencoba mengurai keajegan secara perlahan sebagai bentuk negosiasinya. Selaras dengan pernyataan yang diberikan oleh Yayan (52 tahun, narasumber diskusi bulanan PM), bahwa untuk "mendobrak tatanan masyarakat yang begitu dominan akan sulit karena tatanan itu begitu besar sehingga ketika berbalik ke kita yang terasa hanyalah rasa sakit". Beliau mengibaratkan hal tersebut dengan sebuah tembok yang besar, "Kita coba untuk merobohkannya dengan tubuh sendiri, namun yang terjadi hanyalah rasa sakit, lalu bagaimana dengan temboknya? Masih berdiri dengan tegak!". Strategi ampuh yang PM jalankan adalah mencari celah untuk menyadarkan dan memberikan pendidikan mengenai gender dan seksualitas. Walaupun hal itu terkesan sederhana, tetapi besar harapan PM bahwa pesan yang sudah tersampaikan dapat disebarkan oleh partisipan ke khalayak lain. Seiring berjalannya waktu, tembok yang besar 
tersebut dapat terkikis sedikit demi sedikit dan dalam prosesnya akan roboh dengan sendirinya.

Menurut Johan (30 tahun, aktivis), sebagai salah satu inisiator PBK, para anggota mampu mempengaruhi baik di dalam komunitas maupun setelah lepas dari komunitas. Sejalan dengan itu, Ellen (28 tahun, dosen), salah satu co-founder PBK, menyebutkan bahwa modal PBK adalah menawarkan rasa yang berbeda seperti garam dan memberi teladan bagai lilin. "PBK sebagai kelompok maupun individu, tidak mencari popularitas, tidak memilikipemimpin, tidak punya struktur, dan membebaskan anggotanya untuk berpartisipasi sesuai potensinya. Namun di sisi lain, masing-masing anggota juga dapat bergerak secara individual seperti lilin: kecil, sendiri, tapi bercahaya dan menerangi," tuturnya. Berdasarkan paparan tersebut, PBK memiliki strategi yang bergerak tidak hanya ke bawah namun menyebar dan masuk ke lingkungan terdekat masing-masing anggotanya. PBK berharap tidak hanya mereka yang menjadi anggota komunitas yang dapat mempraktikkan hal tersebut, tetapi para peserta diskusi yang tidak terikat langsung dengan PBK juga dapat terinspirasi untuk berjuang dan berjejaring bersama dengan cara mereka masing-masing.

Sementara itu, PM berusaha untuk menghadirkan pengetahuan gender dan seksualitas tanpa berusaha mengharuskan partisipannya berubah. Aris membenarkan hal itu "Kami hanya menyediakan ilmunya saja, jika tidak setuju tidak masalah, hal tersebut bisa didiskusikan". Namun yang jelas, PM berusaha mengacaukan pemikiran-pemikiran yang ajeg dengan menawarkan pemikiran alternatif tersebut. Misalnya, pada saat sesi aborsi yang aman, ada dua peserta yang kontra. Menurut merekatema aborsi ini masih diperdebatkan di masyarakat sehingga mereka meminta diskusi lebih lanjut. Setelah berdiskusi, mereka merasa menemukan sudut pandang baru yang lebih menyegarkan pola pikirnya sehingga dapat menghapus stigma negatif mengenai aborsi. Berdasarkan anggapan tersebut, PM meminjam praktik teori queer yang "mengganggu" pemikiran-pemikiran yang ajeg tentang gender dan seksualitas (Butler, 2004; Ahmed, 2006) sehingga membuat partisipan risih, tetapi mau untuk mempertanyakannya atau pun mendialogkannya dengan cara duduk bersama untuk saling mendengar.

\section{Collective Care}

Penciptaan dan penguatan kepedulian kolektif menjadi harapan bagi kedua komunitas. Hans (30 tahun, mahasiswa pascasarjana), sebagai salah satu pendiri PBK, memaparkan bahwa ide penciptaan PBK bermuara pada ruangbelajar bersama. "Salah satu pilihan untuk merespons intoleransi adalah menciptakan ruang diskusi yang terbuka dan ramah dengan publik," jawabnya. Di sisi lain, PM terbukti menciptakan kepedulian yang dibangun kolektif. Gama (28 tahun, gamer), partisipan diskusi PM, menyebutkan dengan gamblang, "Saya menunggununggu PM yang sebulan sekali dengan antusias karena saya membutuhkan ruang untuk bertemu dengan orang-orang yang peduli dengan saya". Aris juga menambahkan bahwa, "Energi semua yang hadir di sini merupakan kekuatan dan saya bisa merasakan kepedulian teman-teman secara kolektif di ruangan ini". Hal-hal itulah yang menjadi motivasi untuk menggunakan pendekatan akar rumput sebagai alternatif aktivisme.

Ruang alternatif yang diciptakan PBK dan PM dipahami bukan untuk menjadi lawan dari ruang-ruang dominan/arus utama, melainkan sebagai ruang queer yang meleburkan batasbatas antarmanusia untuk berproses bersama. Salah satu hal yang dilakukan PBK adalah kaderisasi dengan model pembelajaran berbentuk kelompok belajar. Model tersebut dipilih karena pada umumnya forum-forum diskusi yang membahas isu-isu minoritas masih terfragmentasi dengan peserta berskala besar. Menurut Rena, PBK membicarakan banyak hal seperti persinggungan antara gender, seksualitas, kesehatan reproduksi, hukum, demokrasi, dan teologi sehingga perlu mempertimbangkan model pembelajaran yang akomodatif. "PBK seperti toko serba ada dan tidak eksklusif, siapapun diterima baik institusi maupun individu," tuturnya.

Berbeda dengan PM, untuk menjaga rasa saling peduli yang bersifat kolektif, PM selalu mengadakan meditasi di akhir diskusi yang dibarengi dengan pelukan hangat dari masingmasing partisipan yang hadir. Meditasi tersebut membantu para peserta untuk membalut luka batin karena adanya cerita personal yang mereka bagikan pada saat sesi diskusi. Hal tersebut juga digunakan sebagai pengingat bahwa setelah aktivitas PM selesai, para partisipan akan kembali ke rutinitas mereka masing-masing atau masuk kembali ke ruang-ruang heteronormatif. 
Pelukan hangat juga merupakan bentuk kepedulian kolektif untuk menguatkan satu sama lain. Hal serupa pun diutarakan oleh Irvin (35 tahun, karyawan swasta), "Awalnya canggung untuk berpelukan, tetapi ruang PM membuat saya percaya bahwa walaupun kami baru saling mengenal, pelukan tersebut adalah kehangatan dan bisa menguatkan hari saya".

Dalam kasus PBK, Johan memiliki pandangan bahwa PBK merupakan kolektif kecil yang berjejaring untuk mengimbangi media dan ruang-ruang arus utama. Keadaan tersebut dilakukan karena penyebaran informasi dikuasai oleh media mainstream. "Kaum minoritas dapat saja menggunakan media dan ruang mainstream tersebut, tetapi akan ada penekanan dan proses seleksi yang membatasi," urainya. Hal itu disebabkan karena setiap ruang dan media tidak bebas nilai. PBK terbentuk sebagai komunitas yang organik karena berawal dari kelompok kecil yang bertumbuh menjadi kelompok besar. Hal itu yang membedakannya dengan ruang dan media arus utama yang memiliki kapital yang besar. Ellen menambahkan bahwa jaringan PBK berasal dari para anggotanya yang sudah memiliki jaringan sendiri-sendiri. "Teman-teman sudah punya modal masing-masing. Ketika menjadi agen, kami menggabungkan jaringan sehingga menjadi rangkaian jaringan yang indah dan strategis," tuturnya.

Kepedulian kolektif yang dibangun PBK dan PM juga terlihat dengan lahirnya kelompok pendukung (support group) yang dibentuk untuk saling menguatkan dalam menerima perbedaan yang ada dalam diri maupun orang lain. Hal yang penting adalah bagaimana membagi peran. Tidak semua komunitas harus bergerak dengan kelompok marginal saja. Perlu ada komunitas yang mengorganisasi kelompok akademisi dan kalangan terdidik lain. Kepedulian kolektif dapat dibentuk ketika ada ruang yang mempertemukan kalangan aktivis dan akademisi. Ruang diskusi publik akan menjadi hangat dengan terciptanya ruang-ruang yang masyarakatnya bebas berdialektika. Tindakan komunikasi yang ditawarkan Jürgen Habermas dalam proses demokrasi diimplementasikan oleh PBK dan PM. PBK melalui pendidikan publik alternatif kritis telah mewujudkan partisipasi masyarakat sipil yang terliyankan untuk menuju demokrasi yang deliberatif. Sementara itu, PM melalui diskusi bulanannya menjadi titik temu bagi kelompok minoritas gender dan seksual dengan orang-orang yang peduli dan mau mendengarkan cerita mereka. Hal itu menjadi harapan baru di tengah absennya pendidikan gender dan seksualitas dalam sistem edukasi formal di Indonesia serta respons masyarakat sipil atas intoleransi terhadap keberagaman gender dan seksualitas.

\section{Aksi Kreatif}

Sebagai bentuk kreativitas PBK dan PM, metode belajar dibuat dengan kreatif seperti menggunakan seni, film, sastra, dan kunjungan ke tempat-tempat publik untuk belajar dan mengenal dunia sekitar dengan perspektif yang baru. Selain itu, pembuatan konten sosial media dan materi publikasi juga diselaraskan dengan nafas perjuangan PBK dan PM. PBK, misalnya, membuat konten yang menggugah semangat penerimaan terhadap keragaman seksualitas dan ras/etnis. Bahasa yang digunakan sederhana dan menggunakan desain grafis populer. Hal ini menjadi salah satu strategi PBK untuk dapat menyebarluaskan pesan dan menyasar siapa saja, secara khusus kelas menengah terdidik. Lain halnya dengan PBK, untuk meningkatkan partisipasinya dalam penggunaan sosial media, PM melakukan engagement dengan akun-akun yang bergerak di isu yang sama atau pun memiliki perlintasan isu dengan PM sehingga jejaring antarkomunitas melalui sosial media terbentuk.

Dalam menyebarkan informasi aktivitas, PM menggunakan poster-poster yang interaktif dengan menggunakan teknik kolase. Pendiri PM, Aris dan Soka (29 tahun, peneliti) mengungkapkan poster-poster yang dibuat dengan teknik tersebut tidak hanya membentuk ciri khas PM dalam berkomunikasi, melainkan juga untuk menyampaikan pesan-pesan tertentu yang sangat berkaitan dengan tema-tema yang diusung. Poster-poster yang dibentuk memiliki pesan perjuangan, sindiran, ataupun kepekaan terhadap tema yang sedang menjadi fokus perhatian PM. 


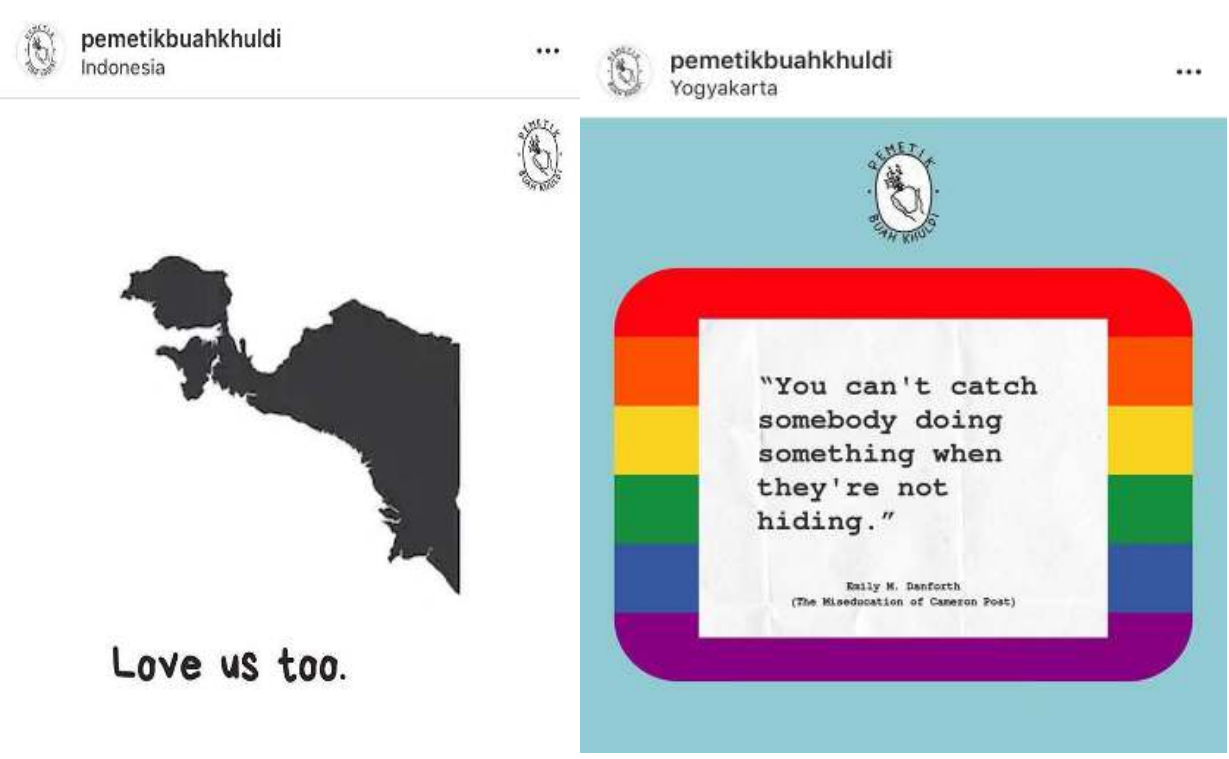

Gambar 1

Konten Instagram PBK yang mendukung keberagaman

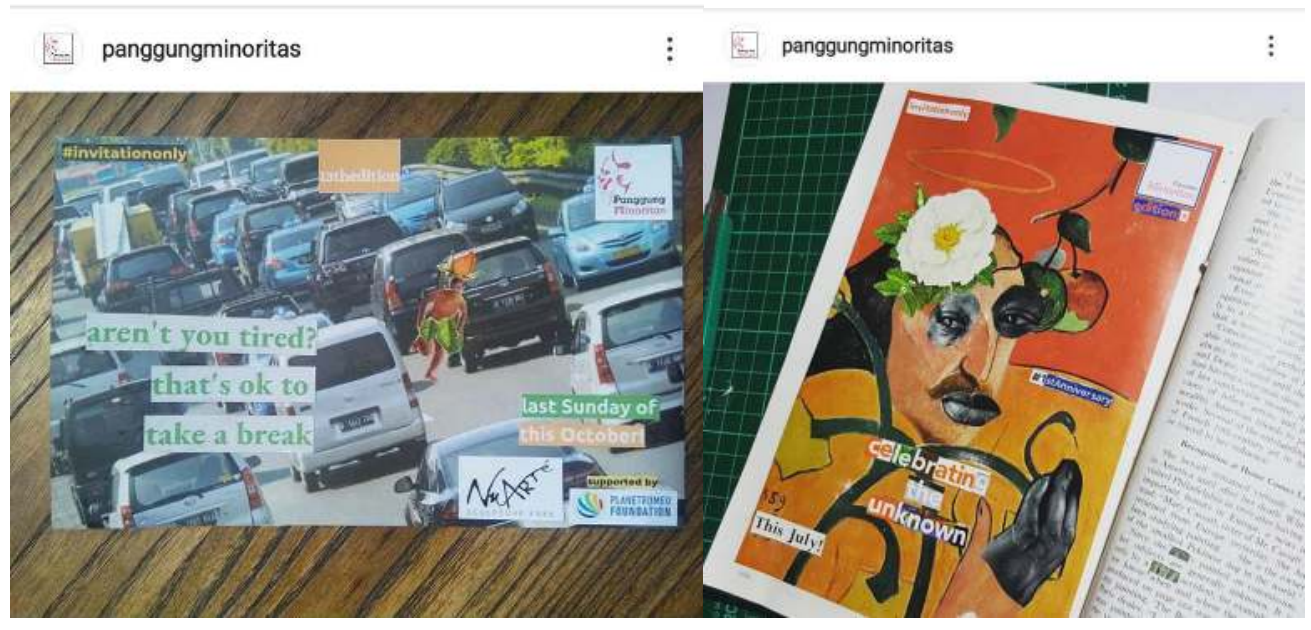

Gambar 2

Konten Instagram PM Mengenai Poster Diskusi Bulanan

Konten sosial media dan materi publikasi yang dibuat oleh PBK dan PM juga menyimpan strategi politik bahasa. Pemilihan kata seperti "cinta", "keberagaman", "rumah bersama", "berjuang", "hati”, "perjalanan", dan "penerimaan" dipilih bukan tanpa maksud. Berkaca pada teori Julia Kristeva (1984) mengenai bahasa puitika sebagai strategi politik dalam membalikkan narasi dominan yang heteronormatif dan patriarkal. PBK dan PM sangat tahu dan menyadari pesan-pesan yang mereka konstruksi. Lebih jauh, PM telah memperluas bahasa dari semantik menjadi tindakan. "Pelukan", "senyuman", dan "sapaan yang hangat" adalah bahasa liyan untuk saling menghibur dan menguatkan. Dalam ruang diskusi PBK dan PM, manusia tidak lagi dilihat dari identitas yang melekat atau dilekatkan pada mereka. Manusia adalah subjek itu sendiri. Mereka berdaulat dan patut dihormati keberadaannya di tengah-tengah dunia ini.

Model lain aksi kreativitas adalah dengan menggelar workshop. PBK membuat workshop yang bertujuan untuk membicarakan isu-isu minoritas sambil membuat kerajinan tangan sekaligus menjadi ruang bagi komunitas untuk membiayai dirinya sendiri. Sampai saat ini, PBK secara mandiri membiayai dirinya 
dengan menggunakan iuran anggota komunitas. Berbeda dengan PBK, PM bisa dibilang tercukupi dengan jalinan kerjasama lintas institusi melalui bantuan dana dari lembaga donor. PM melakukan jejaring yang lebih luas tidak hanya di Bandung saja, melainkan juga melakukan kerja sama dengan institusi atau organisasi nasional dan internasional lainnya. Keduakomunitas memiliki caranya masingmasing untuk bertahan dan mempertahankan keberlangsungan komunitas.

Dalam perjalanannya, PM juga memperluas ruangnya untuk belajar melalui pengadaan klub baca yang bernama Poliroman. Sama halnya dengan kegiatan diskusi bulanan mengenai gender dan seksualitas, klub baca Poliroman diadakan satu bulan sekali. Namun, jumlah partisipan sangat terbatas dengan skala kecil. Klub baca tersebut dibentuk berdasarkan minat partisipan PM yang menginginkan adanya pembacaan teks apapun yang disukai, tetapi konteksnya tidak lepas dari isu queer. Teks yang digunakan sangat beragam, bisa berasal dari buku, komik, majalah, reklame, atau apapun yang berhubungan dengan teks. Klub baca tersebut biasanya sudah memiliki tema tertentu sehingga partisipan yang hadir bisa memilah bacaan mana yang berhubungan dengan tema tersebut atau partisipan membahas satu topik dari teks tertentu sehingga pembacaannya bisa sama, tetapi interpretasinya bisa berlainan dan layak didiskusikan bersama.

Aksi kreatif PBK dan PM bukan tidak mungkin sering berhadapan dengan tantangan. Tantangan tersebut lahir dari kewaspadaan untuk mencegah terjadinya hal-hal yang bersifat intimidatif sehingga mengganggu kelangsungan aktivitas kedua komunitas tersebut. Meskipun belum pernah mendapat intimidasi baik dari pemerintah atau kelompok religius ekstrimis yang ada di Yogyakarta dan Bandung, PBK dan PM berhati-hati dalam menyebarkan informasi penyelenggaraan di setiap kegiatannya. Dalam posternya, PM tidak pernah mencantumkan lokasi kegiatan yang mereka akan lakukan untuk melindungi partisipan diskusi. Hampir serupa dengan PM, meski lebih lunak, PBK tidak mencantumkan lokasi kegiatan apabila tema diskusi dianggap berpotensi memicu ketegangan. Selain itu, kedua komunitas juga melakukan seleksi partisipan yang akan mengikuti kegiatan dengan memeriksa akun media sosial. Pilihanpilihan tindakan itu berkaitan erat dengan cara PBK dan PM bernegosiasi dengan sistem keamanan dan geopolitik Yogyakarta dan Bandung yang terkadang tidak mendukung.

\section{Penutup}

Bagi PBK dan PM, upaya menuju integrasi bangsa merupakan suatu pencapaian yang utopis tanpa usaha dari segenap elemen masyarakat. Mimpi tersebut sekadar khayalan belaka jika masih ada pembeda yang tajam antara wacana mayoritas-minoritas. Walaupun demikian, kita tetap boleh memelihara harapan, meskipun menunggu munculnya kesadaran sikap pemerintah, kaum elit, dan mayoritas lain untuk memperbaiki kegagalan dalam merawat kebhinekaan serta menghadapi atau menyikapi isu-isu minoritas tampaknya akan memakan waktu yang lama untuk memetik hasilnya.

Namun, bukan berarti minoritas menyerah dengan keadaan dan diam menghadapi persoalan tersebut. Mereka menjadikan keadaan, tantangan, dan situasi yang tidak mengenakkan itu sebagai kekuatan untuk bernegosiasi dan menciptakan alternatif-alternatif sehingga mereka bisa bangkit dari kenestapaan hingga berdiri di atas kaki mereka sendiri. Inisiasi dan gerakan yang berasal dari, untuk, dan oleh lapisan akar rumput mencerminkan apa yang telah dilakukan oleh PBK dan PM di Yogyakarta dan Bandung untuk terus melakukan negosiasi tersebut. Ide mencipta ruang memungkinkan kedua komunitas untuk terus berproses secara kreatif dalam menciptakan ruang-ruang alternatif belajar, bertemu, dan berdiskusi secara sehat dan kritis mengenai isuisu minoritas. Tujuan kedua komunitas tersebut adalah mendorong kesadaran dan menciptakan kepedulian kolektif untuk terus peka terhadap permasalahan-permasalahan yang ada dan yang akan berdampak pada minoritas. Dengan menciptakan ruang alternatif, representasi diri dan suara liyan dapat muncul dan perlahan-lahan naik dan didengarkan oleh "langit": pemerintah, elit, dan mayoritas.

Merawat ruang-ruang alternatif bagi liyan adalah usaha untuk menggapai langit. Negara harus diingatkan bahwa perlindungan dan akses yang terbuka wajib disediakan kepada semua warganya tanpa perbedaan. Ruang-ruang tersebut menjadi tandingan bagi ruang-ruang publik yang dikuasai dan dikontrol mayoritas. Ruang alternatif liyan bukan dibuat untuk menjadi jembatan memasuki ruang-ruang publik mayoritas. Akan tetapi, ruang alternatif hadir agar liyan memiliki ruang yang aman dan 
terbuka untuk berekspresi dan merayakan keunikannya. Ruang alternatif itu menunjukkan bahwa minoritas ada dan aktif dalam partisipasi publik. Kini, mereka menunggu untuk mendapatkan respons dari langit.

\section{Daftar Pustaka}

Ahmed, S. (2006). Queer phenomenology: Orientations, objects, and others. Durham: Duke University Press.

ASEAN SOGIE Caucus (2018). Fact Sheet: Escalating violence based on sexual orientation, gender identity, and gender expression (SOGIE) in Indonesia. Quezon City: ASEAN SOGIE Caucus.

BBC. (2016). "Pesantren Waria di Yogyakarta Ditutup, LBH Protes". dilansir dari BBC.com (https://www.bbc.com/indonesia/berita indonesia/2016/02/160225_indonesia ponpes_waria_ditutup) diakses 25 Maret 2020.

Browne, K. dan Nash, C.J. (2010). Queer Methods and Methodologies: Intersecting Queer Theories and Social Science Research. UK \& USA: Ashgate Publishing Company.

Butler. J. (2004). Undoing Gender. New York: Routledge.

Das, S. (2011). The Singing Subaltern, Parallax, 17:3, hal. 4-18, DOI: 10.1080/13534645. 2011.584409.

de Jong, E. \& Twikromo, A. (2017). Friction within harmony: Everyday dynamics and negotiations of diversity in Yogyakarta. Journal of Southeast Asia Studies, 48 (1), pp. 71-90.

Edelman, M. (2001). Social Movements: Changing Paradigms And Forms and Politics. Annual Review of Anthropology, 30(1), 285-317. DOI: 10.1146/annurev.anthro.30.1.285.

Festenstein, M. (2004). Deliberative Democracy and Two Models of Pragmatism. European Journal of Social Theory, 7(3): 291-306. DOI: $10.1177 / 136843$ 1004044194 .

Formichi, C. (2012) Islam and The Making of Nation: Kartosuwiryo and Political
Islam in 20th Century Indonesia. Leiden: KITLV Press

Freedman, A \& Tiburzi, R. (2012). Progress and Caution: Indonesia's Democracy. Asian Affairs: An American Review, 39:3, 131156, DOI:10.1080/00927678.2012.704832.

Gieseking, J.J. (2013). A Queer Geographer's Life as an Introduction to Queer Theory, Space, and Time in Queer Geographies: Beirut, Tijuana, Copenhagen. Roskilde: Museum of Art Contemporary, 4-31.

Hardiman, F. B. (2009). Demokrasi Deliberatif: Menimbang 'Negara Hukum' dan 'Ruang Publik' dalam Teori Diskursus Jürgen Habermas. Yogyakarta: Kanisius.

Halberstam, J. (1998). Female Masculinity. USA. Duke University Press.

Halbertsam, J. (2011). The Queer Art of Failure. Dunham: Duke University Press.

Hiddleston, J. (2007). Spivak's 'Echo': theorizing otherness and the space of response. Textual Practice, 21:4, 623-640. DOI: $10.1080 / 09502360701642359$.

Kristeva, J. (1984). Revolution in Poetic Language. New York: Columbia University Press.

Spivak, G.C. (1988). Can the Subaltern Speak? in Marxism and the Interpretation of Culture by Cary Nelson dan Lawrence Grossberg (ed). Macmillan Education Ltd: London, hal. 271-313.

Mietzner, Marcus \& Muhtadi, Burhanuddin. (2019). The mobilisation of intolerance and its trajectories: Indoensian Muslims' view of religious minorities and etnic Chinese in Contentious Belonging: The Place of Minorities in Indonesia. Singapore: ISEAS Publishing.

Nasir, M.A. (2014). The 'Ulamā', Fatāwā and Challenges to Democracy in Contemporary Indonesia. Islam and Christian-Muslim Relations, 25:4, 489-505. DOI: 10.1080/ 09596410.2014 .926598 .

Ridwan, R., \& Wu, J. (2018). "Being young and LGBT, what could be worse?" Analysis of youth LGBT activism in Indonesia: challenges and ways forward. Gender \& Development, 26(1), 121-138. DOI: 10.1080/13552074.2018.1429103 
Parker, L. (2017). Intersections of Gender/Sex, Multiculturalism and Religion: Young Muslim Minority Women in Contemporary Bali, Asian Studies Review, 41:3, 441458,DOI:10.1080/10357823.2017.1332004.

Suryana, A. (2019). State Officials' Entanglement with Vigilante Groups in Violence against Ahmadiyah and Shi'a Communities in Indonesia. Asian Studies Review, 43:3, 475-492, DOI: 10.1080/10357823.2019. 1633273.
Soedirgo, J. (2018). Informal networks and religious intolerance: how clientelism incentivizes the discrimination of the Ahmadiyah in Indonesia. Citizenship Studies, 22:2,191-207, DOI: 10.1080/ 13621025.2018.1445490.

Widhana, Dieqy Hasbi. (2017). "Saat Pemerintahan Jokowi Membiarkan Pemberangusan Ahmadiyah", dilansir dari Tirto.id (https://tirto.id/cq7p) dan diakses pada 25 Maret 2020. 
